Przegląd Prawa Konstytucyjnego

-ISSN 2082-1212---------

DOI 10.15804/ppk.2016.06.07

$-\mathrm{Nr} 6$ (34)/2016

Ilton Robl Filho ${ }^{1}$

Ingo Wolfgang Sarlet ${ }^{2}$

\title{
Freedom of Speech in the Federal Constitution of Brazil and the Problem of its Collision with other Fundamental Rights, particularly personality rights
}

Keywords: Democratic Rule of Law, Freedom of Speech, Fundamental Rights, Collision, Balancing

Słowa kluczowe: demokratyczne państwo prawa, wolności słowa, prawa podstawowe, kolizja, równoważenie

\section{Summary}

The fundamental right to freedom of speech is a central element of the rule of law in a democratic state that constantly collides with other fundamental rights. Both in court decisions and in legal literature there is a significant discussion on the limits of the freedom of speech, mainly concerning its collision with other fundamental rights, particularly personality rights. This debate has become very strong in Brazilian constitutional case law, mainly in the Federal Supreme Court (Supremo Tribunal Federal), but also in other constitutional systems and even in the domain of international law. Based on the decisions of the Brazilian Supreme Court and those of the US Supreme Court and the Federal Constitutional Court of Germany, this paper aims to discuss some criteria that may guide Courts when balancing freedom of speech and other fundamental rights.

1 Doctor of Law (UFPR) and post-Doctor of Law (PUCRS), Associate Professor of UFPR and UPF and lawyer.

$2 \mathrm{PhD}$ and post-Doctor of Law (F.M.U.-München), Professor of PUCRS and Appeals Court judge. 


\section{Streszczenie}

Wolność słowa w Konstytucji Federalnej Brazylii i problem jego kolizji $z$ innymi prawami podstawowymi, w szczególności prawami osobistymi

Podstawowe prawo do wolności słowa jest głównym elementem praworządności w państwie demokratycznym, które nieustannie zderza się z innymi prawami podstawowymi. Zarówno w orzecznictwie sądowym, jak i doktrynie, trwa dyskusja o granicach wolności słowa, dotycząca przede wszystkim jego kolizji z innymi prawami podstawowymi, w szczególności prawami osobistymi. Debata ta stała się bardzo intensywna w związku z brazylijskim orzecznictwem konstytucjnym, głównie Federalnego Sądu Najwyższego (Supremo Tribunal Federal), ale także w innych systemach konstytucyjnych, a nawet w prawie międzynarodowym. Na podstawie decyzji Sądu Najwyższego Brazylii, a także Sądu Najwyższego USA i niemieckiego Federalnego Trybunału Konstytucyjnego, opracowanie to ma na celu przybliżenie pewnych kryteriów, którymi mogą kierować się sądy przy orzekaniu o wolności słowa i innych prawach podstawowych.

\section{I.}

The discussion on freedom of speech in general and freedom of the press in particular is one of the most stimulating and complex topics of constitutional law as well as universal and regional international law of contemporary human rights. In Brazil this debate was further emphasized due to the Supreme Court's decision - with the opinion issued by High Court Justice Carlos Britto - in ADPF [Claim of Non-compliance with a Fundamental Prescription] No. 130/DF, to not consider "incorporated" Law No. 5,250 (1967), usually known as "Press Law", by the 1988 Federal Constitution (hereafter only BFC $=$ Brazilian Federal Constitution), highlighting the prohibition - mentioned by the author of the opinion -of regulating the aforementioned freedoms, arguing that freedom of speech is almost absolute as only the limitations expressly established by the BFC, in particular the prohibition of anonymity, the right to later compensation and the right of reply, are applicable. 
By that decision, a regulatory void at the level of ordinary legislation in the domain of the freedom of speech was created to a greater or lesser extent ${ }^{3}$, without prejudice to some partial regulation, for instance the right to reply in electoral disputes and currently in other social communication media, in accordance with Law No. 13,188/2015, leaving most questions to be examined by the judiciary. In turn, magistrates in general have proven to be strong advocates of the freedom of speech, particularly freedom of the press or, in the broadest sense, media freedom, suggesting even - in spite of the well-known controversy on the subject - that also in Brazil one can support (at least in the view of the Brazilian Federal Supreme Court - hereafter only BFSC) a preferred position of the freedom of speech in the broader context of fundamental rights and guarantees.

In this context, our purpose is to situate the issue of the restraints on freedom of speech in a democratic state, as enshrined in the BFC, without intending to exhaust the range of issues raised by this matter, given its diversity, heterogeneity and complexity, without prejudice to its repercussion on the criminal, administrative and civil spheres, to mention only the most current legal cases. In short, although prioritizing the Brazilian constitutional perspective, our aim here is to use some examples from foreign law (emphasizing the USA and to a lesser extent Germany) and to explore the way in which the BFSC has dealt with the issue and the criteria applied to the solution of such conflicts, including a critical reflexive analysis that may contribute to the advancement of the discussion in Brazil.

Thus, after a brief analysis of the position and content of freedom of speech in a democratic state, with emphasis on the BFC (2), we will discuss the restraints on freedom of speech, in particular the so-called collisions with other fundamental rights and the criteria adopted for their solution (3), which will be followed, at the end, by some conclusions (4).

3 This problem, in particular the discussion on the constitutional provision regulating the social communication media, its modes of implementation and its various aspects will not be developed here. 
II.

Although there are some common elements, a trend that appears to be irreversible, at least considering the strong proximity of Western European, Anglo-Saxon and Latin American legal traditions and cultures, there is no universally valid and correct answer to the content and restraints on freedom of speech in general and to the way of solving the collision between freedom of speech and the so-called personality rights, for instance right to privacy, image and honor.

In relation to these rights, a prominent position is given to honor, image and privacy, but also to the collision with other constitutional rights, such as - and this is becoming increasingly emblematic - religious freedom, protection of children and adolescents, as well as internal and external public security - in this respect, suffice it to point out the problems of organized crime and terrorism.

Thus, in order to make the subject easier to understand and to illustrate with examples the lack of uniformity in the treatment of the matter, we start with three cases taken from real-life situations which are related to that conflict involving decisions made by the Supreme Courts (operating as constitutional courts in each case) of the three countries selected for the purposes of this article.

Case 1. The Governor of Bavaria (Federal Republic of Germany) was depicted as a pig in several comic strips of a magazine with strong political leanings and funded by a left-wing party. In these drawings the politician is seen having sex with a sow wearing a court gown. The purpose of the pictures is to report supposedly promiscuous activities between politicians and members of the judiciary ${ }^{4}$.

Case 2. Making it quite clear that the information in this story was not true, a US pornographic magazine published a fictional interview with a religious leader, an advocate of traditional Christian family values, stating that this personality had had his first sexual intercourse with his mother ${ }^{5}$.

4 Bundesverfassungsgericht (BVerfGE) 75, 3691 BvR 313/85 Strauß caricature-decision, 1987.

U.S. Supreme Court (U.S.SupC). Hustler Magazine, Inc. v. Falwell, 1988. 
Case 3. In Brazil the author of a work of historical revisionism was convicted of racism for denying the Holocaust which resulted in the genocide committed against the Jewish people by the German National-Socialist regime during World War II, and the decision was affirmed by the BFSC ${ }^{6}$.

At first glance, it can be seen that, even considering the need for a distinction concerning the content and form of the dissemination of the respective messages as well as taking into account the differences in the format of each particular legal system and the peculiarities of each legal tradition as far as freedom of speech and its restraints are concerned, in all summarily described cases it is possible to detect a frontal collision between freedom of speech and other constitutional rights and values.

Even if the three cases discuss public issues par excellence, the first case discusses the core of the democratic state's structure and contains clear criticism of a political nature including the separation of powers and their respective image. The second case involves an attack, using sharp irony and even shocking content, on the conservative discourse about family and sexuality. The third case, in turn, deals with the issue of whether that book amounts to so-called hate speech and whether it involves a relativization of the constitutional requirement of strict legality in criminal cases.

At first sight it is clear that although the decisions have several elements in common, the three cases differ in many respects.

Regarding the first case, Germany's Federal Constitutional Court (henceforth only GFCC) ruled: a) that this is a case of artistic freedom, according to art. 5 (3) of the German Federal Basic Law (henceforth only GFBL), which, however, is directly related to freedom of speech; b) that even viewing cartoons as a genre which par excellence uses exaggeration and that public figures are constant targets of social criticism, the drawings in the German magazine Konkret attacked the State of Bavaria's President as a person, violating his dignity, and c) that in this specific case the caricature no longer contained criticism as such, but was basically designed to humiliate and expose the former State President of Bavaria, amounting to what the GFCC called a Schmähkritik, no longer protected under the freedom of speech clause. Thus

6 Supremo Tribunal Federal (STF). Habeas corpus $n$. 82.424/RS. Opinion by Justice Moreira Alves, 2004. 
the trial court's decision to convict of defamation, establishing the payment of a fine, was maintained, and the first court of appeal's legal decision to acquit was overturned.

When judging case number two, the US Supreme Court (henceforth only SC), in the famous case Hustler Magazine Inc. v. Falwell, gave preference to artistic freedom and freedom of speech. It should be noted that Jerry Falwell, a leading religious authority and US public figure, sued the pornographic magazine Hustler and its editor Larry Flynt for attacking his privacy, for defamation and for intentional offensive and harmful behavior and the infliction of moral distress. Larry Flynt was sentenced to pecuniary civil compensation for the violation of the religious and psychic integrity of Jerry Falwell. But the SC overturned the decision of the lower courts arguing that a) freedom of expression is essential to the free flow of ideas and thoughts on issues of public interest and that $b$ ) this freedom, in addition to being an individual right, guarantees access to the truth and society's vitality. Besides this, the Hustler Magazine Inc. v. Falwell case is part of the tradition built by the $\mathrm{SC}$ in the course of the $20^{\text {th }}$ century ensuring that freedom of speech maintains a preferred position among other constitutional rights and guarantees?

\section{III.}

In view of the above considerations and collated examples, it appears that the manner of dealing with and solving the main problem of the text, namely, solving collisions (conflicts) between freedom of speech and other fundamental rights and/or constitutionally protected interests, is indeed very diverse, which also has to do with the position, function and scope granted to freedom of speech in each legal and constitutional order, either due to positive constitutional law in constitutional texts or by the hierarchy under the Federal Constitution legislator's work, but also, and especially, by the courts and, in particular, the courts protecting the constitution.

Under the 1988 Federal Constitution, freedom of speech (or communicative freedoms) was the object of a more detailed regulation, corresponding, at

7 On the history of the freedom of speech in North America, see, C.R. Sunstein, Democracy and the problem of free speech, New York 1995, p. 4. 
least according to the constitutional text, to the level of recognition and protection compatible with an authentic democratic state.

In this context and still in a preliminary stage, it must be observed that, under the prevailing doctrine and jurisprudence, including the Supreme Court, we decided to use the generic term freedom of speech, as a concept that encompasses both the free expression of thought, under Articles 5, item IV of the Constitution, and the other dimensions of freedom of speech. Freedom of speech, therefore, as Jónatas Machado suggested, will be here treated as a kind of "mother-right", contradicting a fragmented approach which part of the specialized literature tends to establish between the freedom of communication and of speech ${ }^{9}$. Thus, the various fundamental prerogatives linked to freedom of speech will be analyzed not as a mere conglomerate, but as interrelated parts of a general concept, which calls for a systematic and integrated approach, preserving, however, the peculiarities of each specific fundamental right ${ }^{10}$, which will be considered in subsequent developments, when, after a general part on freedom of speech, the most relevant aspects of each freedom (right) in particular will be examined.

These differences, however, do not preclude the consideration, which is presupposed in this article, of the premise adopted by the Supreme Court and the dominant Brazilian doctrine (which in this respect is closer to the US than to Germany) on the inclusion of freedom of speech (and freedom of the media) in a uniform regime. Obviously, in relation to other freedoms placed in the general context of freedom of speech, as in the case of freedom of teaching and research, freedom of assembly and demonstration, artistic freedom and religious freedom, the BCF itself sets guidelines and even specific restraints that in this case must be observed. However, these will not be studied here.

8 See J.E.M., Machado, Liberdade de expressão: dimensões constitucionais da esfera pública no sistema social, Coimbra 2002, p. 370.

9 See, for example, the path trodden in the case of Brazilian literature, by E. Farias, Liberdade de expressão e comunicação: teoria e proteção constitucional, São Paulo 2004, especially p. 52 , although it is necessary to record that the author also supports a broad scope of protection of both freedoms, presenting a detailed range of legal prerogatives covered by them.

10 See Art. 5, Meinungsfreiheit, Pressefreiheit u.a. [In:] Stern-Becker, Grundrechte-Kommentar, Köln 2010, p. 530. 
Yet, as regards the role of freedom of speech in the democratic rule of law it is widely acknowledged to be one of the most precious fundamental rights and corresponds to one of the oldest human needs. Hence it is integrated into the rights expressed in the constitution from the first modern phase of constitutionalism ${ }^{11}$. Just as freedom of speech and thought build their main foundations (and objectives) on the dignity of the human person, in relation to autonomy and the free development of individual personality, this freedom is also related, in a social and political dimension, to the conditions and the guarantee of democracy and political pluralism, ensuring a kind of free market of ideas and assuming, in this sense, a quality of a political right with a clearly transindividual dimension ${ }^{12}$, as freedom of speech and its respective restraints essentially operate in the sphere of communication and social life relations.

Thus, although here there is no reason to further explore this issue, the Court notes that the relationship between democracy and freedom of speech is a mutual constraint and assumes a complementary dialectical and dynamic character, because democracy as a rule means more freedom of speech and vice-versa (more freedom of speech indicates more democracy), not excluding, on the other hand, the fact that exercising the right of freedom of speech can pose risks to democracy and the exercise of democracy might possibly impair freedom of speech $^{13}$.

As regards the scope of protection, freedom of speech as a fundamental right encompasses a diverse set of situations, basically covering a number of freedoms (faculties) with spiritual content, including non-verbal expressions, such as musical expression, communication through arts and others ${ }^{14}$. Freedom of speech consists, more precisely, of the freedom to express opinions,

11 See, P.G. G. Branco, Liberdades, [In:] Mendes G.F., Branco P.G. G., Curso de direito constitucional, 6 $6^{\text {e }}$., São Paulo 2011, p. 296.

12 In this sense, see, pars pro toto, J.E.M. Machado, op.cit., p. 237, who attaches to freedom of speech essentially an instrumental character, therefore, it is not an end in itself.

13 From this perspective, see, F. Michelman, Relações entre democracia e liberdade de expressão: discussão de alguns argumentos, [In:] Direitos fundamentais, informática e comunicação, eds. I.W. Sarlet, Porto Alegre 2007, p. 49.

14 See L. Michael, M. Morlok, Grundrechte, Baden-Baden 2008, p. 126 e, no direito brasileiro, P.G. G. Branco, op.cit., p. 297. 
namely judgments about facts, ideas, opinions of third parties, etc. ${ }^{15}$ Thus, it is freedom of opinion which is at the basis of all modes of freedom of speech ${ }^{16}$, including the concept of opinion (which, in the BFC language was ultimately equated to the concept of thought) and adopted in a broad and inclusive manner, embracing, just to make it clearer, manifestations about facts and not only value judgments ${ }^{17}$. It should be added that besides protecting the content, i.e. the object of expression, the means of expression are broadly, openly and inclusively protected, as in the case of electronic communication ${ }^{18}$.

An elastic understanding of the scope of protection runs up against some controversial issues, as for instance the denial of historical facts or even as far as the existence of the duty of producing the evidence that will change the outcome is concerned, as well as with regard to so-called crimes of opinion, since, in such cases, there have been great controversies regarding their inclusion within the sphere of protecting freedom of speech), which refers to the problem of the sphere of protection and the restraints of freedom of speech, which will be the object of attention in the next segment ( 3 below).

In relation to its condition as a fundamental right, it should still be recalled at this conceptual stage that freedom of speech in its various manifestations encompasses both the right (faculty) of a person to express and not to express themselves or even not to inform themselves ${ }^{19}$. Thus, first and foremost, freedom of speech assumes the essential condition of the right to defense (negative right), operating as the person's right not to be hindered in expressing and/ or disclosing their ideas and opinions, although without prejudice to a cor-

15 See V. Epping, Grundrechte, $3^{\text {rd }}$ ed., Berlin-Heidelberg-New York 2007, p. 86.

16 According to J.A. da. Silva, Curso de direito constitucional positive, $28^{\text {th }}$ ed. rev. and updated. São Paulo 2007, p. 241, the freedom of opinion "summarizes the freedom of thought itself in its various forms of expression. That is why the doctrine calls it a primary freedom and starting point of others. It is an individual freedom to adopt the intellectual attitude of one's choice: either an intimate thought, or a public position taken; freedom to think and say what one believes to be true." For the author, by adhering to a broad concept, freedom of opinion "is externalized by the exercise of freedom of communication, religion, intellectual, artistic, scientific, cultural expression and transmission and reception of knowledge" ibidem, p. 243.

17 See, L. Michael, M. Morlok, op.cit., p. 128.

18 See J.J.G. Canotilho, V. Moreira, Constituição da República portuguesa anotada, $4^{\text {th }}$ ed., Coimbra 2007, p. 572, adopting a broader conception in the sphere of protection of freedom of speech.

19 See, P.G. G. Branco, op.cit., p. 298. 
relative positive dimension, since freedom of speech implies a right to access the means of expression, which does not necessarily mean free direct access to social means of communication ${ }^{20}$, although this component has also become increasingly important at various times (in the Brazilian case, for example, the access of political parties to the media for the purpose of disseminating their programs, candidates, etc.), which is seen with greater interest because of the objective dimension of freedom of speech.

Indeed, also in relation to freedom of speech, it has been verified that it presents a dual subjective and objective dimension, namely, operating both as an individual subjective right (and even collective, depending on the particular case), of a negative nature (implying negative rights), or, depending on the particular case, involving subjective rights to benefits.. These, in turn, are strongly linked to the objective dimension, which requires duties of protection supplied by the state, partly fulfilled by the issuance of procedural norms and, on the other hand, also realized by the creation and regulation of institutions (entities) which protect and promote rights. As to the duties of the state, at the constitutional level there is the Social Communication Council (Art. 224, FC), which will not be thematized here, and such duties are also binding on judicial institutions, ensuring not only the proper consideration of rights and interests that are at stake, specifically in the realm of relations between private individuals, but also controlling the constitutionality of state acts which interfere with freedom of speech. Indeed, the role of the judiciary in this context, exercising the duty to protect, is particularly important, complex and controversial in the context of conflicts between freedom of speech and other fundamental rights, in besides the judicial review of constitutionality when rights are restrained by state agencies, which will be discussed in a moment.

\section{IV.}

Due to its relevance to democracy and political pluralism, freedom of speech at least according to a significant doctrine in Brazil and in the United States takes on a kind of preferred position when resolving conflicts with other con-

20 See J.J.G. Canotilho, V. Moreira, op.cit, pp. 572-573. 
stitutional principles and fundamental rights ${ }^{21}$. Although it is stated that, in Brazil, the theory of preferred position is adopted, as enshrined by the Supreme Court on the occasion of ADPF No. 130, this theory is generally timidly applied ${ }^{22}$, and, on the other hand, it is not recognized by the majority in $\mathrm{n}$ Germany and, generally, in Europe, where freedom of speech does not assume a prior preferred position in the fundamental rights architecture. Anyhow, even if it is accepted (an aspect about which particular skepticism is shown considering the peculiarities of the Brazilian positive constitutional law), the doctrine of the preferred position is not a matter of attributing to freedom of speech (in any of its particular manifestations) the condition of a right that is completely immune to any restraint and restriction, nor of establishing a kind of prior hierarchy among the constitutional norms

Thus, when it comes to a preferred position, one seeks to recognize freedom of speech in a position of advantage in the case of conflicts with other fundamental rights with regard to the hierarchy of conflicting positions in this specific case ${ }^{23}$. Thus, by solving a possible conflict between freedom of speech and other individual and collective fundamental rights, one cannot fail to consider the proportionality requirements and other criteria applicable to such situations, which one sees practiced even by the BFSC in some situations.

But before dealing with this aspect, it is worthwhile recalling the distinction between expressly established constitutional restraints, such as the prohibition of anonymity (art. 5, IV, BFC) and the prohibition of censorship (art. 5, IX, and $220, \S 2, \mathrm{BFC}$ ) as well as, somehow, part of the right to reply (art. 5. V, $\mathrm{BFC}$ ) and the right to compensation for a disproportionate violation of personality rights not supported by the Constitution (art. 5, X, BFC). Indirect restraints should also not be disregarded, in the sense of being expressly authorized by the BFC and implemented by the legislator (legal reserves) - in this

21 See, in Brazilian doctrine, L.R. Barroso, Colisão entre liberdade de expressão e direitos da personalidade. Critérios de ponderação. Interpretação constitucionalmente adequada do Código Civil e da Lei de Imprensa, "Revista latino americana de estudos constitucionais" Belo Horizonte: Del Rey, 2005, no. 5.

22 R.L.-F. Koatz, As liberdades de expressão e de imprensa na jurisprudência do STF, [In:] Direitos fundamentais no Supremo Tribunal Federal: balanço e crítica, eds. D. Sarmento, I.W. Sarlet, Rio de Janeiro 2011, p. 402.

23 On this topic, see an important contribution made by J.H. Weingartner Neto, Privacidade e liberdade de imprensa. Uma pauta de justificação penal, Porto Alegre 2002, p. 147. 
case, non-existent in the context of freedom of speech in the BFC - and the restraints implicitly authorized by the BFC. These questions are specifically related to problems of conflict between fundamental rights and the imposition of restrictions due to the need to harmonize the fullest possible exercise of freedom of speech with the enjoyment and protection of other fundamental constitutional rights, prerogatives and powers.

Since this text focuses on conflicts between freedom of speech and other rights, the prohibitions of anonymity and censorship, as well as the rights to reply and to compensation will be briefly addressed insofar as they are related to the central theme.

With regard to censorship, the BFC, in Art. 5, IX, in the context of free expression of intellectual, artistic, scientific and communications activities, establishes a categorical prohibition, repeated in Art. 220, \$2, BFC according to which "any kind of political, ideological and artistic censorship is forbidden." It is known that the prohibition of censorship is to such a point relevant to freedom of speech that, according to Jónatas Machado, "freedom of the press is, historically, freedom against prior censorship." 24 In turn, the prohibition of censorship does not waive a definition of what censorship is, even to distinguish between situations in the light of the legal and constitutional system.

In a first approach, since the notion of censorship is widely shared, the censorship that might be considered entirely and in any case absolutely forbidden by the BFC, consists, according to Jónatas Machado's teaching of the prior restriction of freedom of speech made by the administrative authority that results in forbidding the dissemination (publication) of a given content ${ }^{25}$. On the question whether other prior interventions (e.g. established due to the protection of other fundamental rights in the event of a collision between these and freedom of speech) fall within the notion of censorship and to what extent they may be (or not) constitutionally legitimate, there is a heated debate and what prevails is the view that in order to ensure the protection of freedom of speech, the prohibition of censorship and license must be understood in a broad sense. Thus, this prohibition includes not

\footnotetext{
24 See, J.E.M. Machado, op.cit., p. 487.

25 Ibidem, pp. 486-487.
} 
just the typical administrative censorship, but also other hypotheses of prohibition or restraint of freedom of expression and free circulation of information and ideas ${ }^{26}$.

This is observed, for example (here in the Brazilian case), when the Supreme Court, analyzing the constitutionality of the rule contained in articles 20 and 21 of the Civil Code, in the Direct Action of Unconstitutionality [ADI] No. 4815, after a Public Hearing with the participation of major public and private institutions, politicians, lawyers and writers on 21.11.201327, performed an interpretation according to the Constitution by saying that it is "unenforceable to demand the consent of a person about whom a biography is written, regarding literary or audiovisual biographical works, and it is likewise unnecessary to obtain the authorization of people who are portrayed as supporting characters (or their families in the case of deceased persons)."

Nevertheless, although it is necessary to have a broad interpretation of censorship to protect freedom of speech, it is important to distinguish between censorship and other restriction mechanisms (which may, according to the particular case, be constitutionally justified), which is needed even to preserve the characteristics of each form of freedom of speech and even not to assign an absolute character to freedom of speech. Moreover, although the prohibition of censorship is a rule and not a principle, it is an open (undetermined)

26 See, E. Farias, op.cit., p. 188.

27 The following were heard at the Public Hearing: a) Federal Prosecutor's Office (Odim Brandão Ferreira), b) Brazilian Academy of Letters (Ana Maria Machado), c) Brazilian Association of Constitutionalist Democrats (Roberto Dias), d) Brazilian Union of Writers (Alaor Barbosa dos Santos), e) Federal University of Rio de Janeiro (José Murilo de Carvalho), f) Brazilian Association of Independent Television Producers (Leo Wojdojdyslawski), g) Representatives of the Copyright Committee of the Bar Association - Sectional São Paulo (Silmara Chinelato), h) Open Word Institute (Patricia Blanco), i) Newton Lima (Congressman), j) Interstate Union of Audiovisual Industry (Claudio Lins de Vasconcelos), k) Ronaldo Caiado (Congressman), 1) Marcos Rogerio (Congressman), m) National Association of Book Publishers (Sonia da Cruz Machado de Moraes), n) Brazilian Historical and Geographical Institute (Ivar Alberto Martins Harmann), o) Ministry of Culture (Renato de Andrade Lessa) p) Associação Eduardo Banks (Ralph Anzolin Lichote), q) Council of Social Communication of the National Congress (Ronaldo Lemos), r) São Paulo Press Association (Sergio Redó) s) John Ribeiro Moraes (lawyer) and t) the Brazilian Bar Association (Marcus Vinicius Furtado Coelho) See Supremo Tribuna Federal, Ação Direta de Inconstitucionalidade no 4815, Opinion by Justice Carmen Lucia, 2016, pp. 13-22. 
concept which needs to be filled with content. In any case, as Daniel Sarmento points out, an important general guideline to be observed is that restrictions on freedom of speech are permissible only in very exceptional cases, when the protection of rights or other comparative legal interests are involved, since the general rule, which is inferred from the BFC, is that possible abuse and injuries to rights must later be punished and compensated ${ }^{28}$.

The example of unauthorized biographies, in turn, reveals the Supreme Court's position aiming to control the constitutional legitimacy of legal rules enacted hierarchically by law under the Federal Constitution based on the parameters of freedom of speech, as shown in the decision made in ADI [Direct Action of Unconstitutionality] No. 4,815 $5^{29}$. Furthermore, at least as can be inferred from most of the opinions, that decision states that freedom of speech occupies a conditioned preferred position in the context of the constitutional system, but it does not dispense with critical appraisal and a certain acceptance when it conflicts with other fundamental rights and constitutional hierarchy of principles, which can be found also in the case of Supreme Court Justice Carmen Lucia's opinion.

However, despite the relevant and even paradigmatic decisions established in ADPF No. 130 and ADI No. 4815, the complexity of issues relating to freedom of speech, press and information, because of different demands and collisions between these fundamental rights and other constitutional rights and values, so far no full adaptation has been produced for the Supreme Court's

28 See in D. Sarmento, Comentários ao artigo 5o, IV, CF, [In:] J.J. G. Canotilho, G.F. Mendes, I.W. Sarlet, L.L. Streck, Comentários à Constituição Federal de 1988, São Paulo 2013, pp. 252-258.

29 "The object of questioning formulated in face of such constitutional principles and the validity of the widely utilized civil rules in court as legal reasoning for prohibiting decisions on biographies, what one has as core of the judicial inquiry in this decision for which an answer is requested is: a) the constitutional principles are of founding centrality in the current Brazilian legal system and determine the interpretation of the legislation hierarchically under the Federal Constitution norms, including, therefore, those that compose the laws of the civil code; b) it is extracted from a first reading that civil rules configure a protection framework of some fundamental rights, constitutionally protected (right to privacy in particular), formulating prohibitive content rules in horizontal relationship (horizontal dimension of fundamental rights applied to and to be respected in civil relations); c) the general prohibition of civil rules does not make an exception, in its framing, biographical works in normative reference made to the person or their family" (Supremo Tribunal Federal, Ação Direta de Inconstitucionalidade n. 4815, 2016, p. 24). 
interpretation. Therefore it is worth mentioning a few other decisions for illustrative purposes.

For example, in Writ of Prevention No. 17,091 the National Bank for Economic and Social Development (BNDES), by alleging violation of binding precedent No. $10^{30}$, sought to overturn the decision which determined the publication of reports on credit analysis concessions between 2008 and March 2011, which information had been requested by Folha da Manhã S.A. Due to the confidentiality of financial institutions' operations and the judgment of ADPF No. 130, Supreme Court Justice Lewandowksi partially upheld the provisional remedy in order to allow access to reports after BNDES had removed all confidential information from those documents ${ }^{31}$.

The absence of safe criteria or standard interpretation of the collision of freedom of expression with other constitutional rights is clear in the different positions about the in the same legal proceedings. For example, in the Writ of Prevention interim No. 19,464, the National Association of Newspapers (ANJ) applied to the Supreme Court, also alleging infringement of the decision made in ADPF No. 130. In this case, the daily newspaper of the region (Diário da Região, São José do Rio Preto, São Paulo) reported on the Tamburutaca operation of the Federal Police. As the news stories had been published with information from passages obtained through telephone interception of in camera proceedings, the Federal Prosecutor's Office requested the indictment of the reporter for the crime defined in art. 10 of Law No. 9,296/1996.

Although the police investigation concluded that the conduct had been non-offensive, the Federal Prosecutor's Office requested the legal disclosure of the journalist's and newspaper's phone records, and this claim was upheld by the First Level Federal Court and the $3^{\text {rd }}$ Region Federal Court. The National Association of Newspapers' dispute in the sense that ADPF No. 130 established the state's inability to restrict freedom of the press and, consequently, to confront a source's secrecy was accepted by the Supreme Court's presiden-

30 "The decision made by a fractional body of a court that, although it does not explicitly declare the unconstitutionality of a law or a normative act of government, rejects its bearing, in whole or in part, violates the plenary reserve clause (BFC, Art. 97).”.

31 Supremo Tribunal Federal, Reclamação n. 17091, Justice Ricardo Lewandowski, 2014. 
cy during the court recess period by Justice Lewandowski ${ }^{32}$. It should also be noted that after the opinion issued by the Attorney General's Office, the rapporteur of that claim, High Court Justice Dias Toffoli, revoked the provisional remedy previously granted, based on the legal reasoning that freedom of the press is not a justification for criminal conduct ${ }^{33}$.

The collated examples demonstrate that the need to assess the constitutionality of intervention in freedom of speech, in large measure, concerns restrictions which are not directly authorized by the BFC as they result and are required because of the sufficient and simultaneous protection of other fundamental rights, which may be in collision with freedom of the press.

Moreover, the view that freedom of speech, including freedom of information and press (social communication), is also not absolute and finds restraints in the exercise of other fundamental rights and the safeguarding, even in the objective dimension (via the state protection duties), of other legal and constitutional prerogatives and powers, is hardly ever challenged in contemporary constitutional law and even in the sphere of international human rights law. On the other hand, there is still an intense controversy about what these restraints are, as well as about how and to what extent one can intervene in freedom of speech, and it represents one of the major challenges to the legislator and to other judicial bodies, as these take responsibility for the analysis of intervention in a specific case and in the sphere of abstract judicial review and legality, as shown in the examples highlighted in the first part of this article, which are representative of US, German and Brazilian court decisions.

In this context and according to the precise and timely summary by Daniel Sarmento, despite the position taken by Supreme Court Justice Carlos Ayres Britto in the decision made in ADPF No. 130, when he claimed that no legal limit could be imposed on freedom of speech, since the existing restrictions would only be those already enshrined in the Constitution, and the Judiciary's duty was merely to make the relevant considerations in case of conflict with other rights, Supreme Court Justice Gilmar Ferreira Mendes,

32 Supremo Tribunal Federal, Reclamação n. 19464, Opinion by Justice Ricardo Lewandoski, 2015.

33 Supremo Tribunal Federal, Reclamação n. 19464, Opinion by Justice Dias Toffoli, 2015. 
in his opinion in Extraordinary Appeal No. 511,961/SP, noted that restrictions on freedom of speech trough legislation are permissible, provided that they aim at promoting other valuesand equally relevant constitutional interests and respect the principle of proportionality ${ }^{34}$. In fact, even if they are exceptional, the legislative restrictions, which are not expressly authorized need to be brought back to what is established in the BFC as they are based on the protection of other relevant constitutional prerogatives and cannot be rejected, at least not immediately, on the reasoning that these are always constitutionally illegitimate.

In turn, national, foreign and international practices have shown, in the case of restrictions imposed by court decisions, that they usually intend to solve conflicts in particular cases and seek to promote practical concordance (harmonization) between conflicting rights and principles, always applying the notion of restraints of fundamental rights and the criteria resulting therefrom with special observance of the criteria of proportionality and protection of the essential core of the rights concerned.

An example of particular relevance in the context of freedom of speech is the practice of so-called hate speech or incitement to hatred ${ }^{35}$. Here, with respect to the Brazilian tradition, freedom of speech is subject to restraints because of the human dignity of all persons and groups affected when it is used to disseminate messages with discriminatory content aimed at inciting hatred and even violence. In this sense, the Supreme Court considered the famous but no less controversial case of Ellwanger, collated in the introduction, in which the possibility was assessed of, even in the face of freedom of speech, condemning authors whose works reveal anti-Semitic contents for committing the crime of racism ${ }^{36}$.

34 See D. Sarmento, Comentários ao artigo $5^{\circ} \ldots$, pp. 252-258.

35 About the topic see, among others, D. Sarmento, A liberdade de expressão e o problema do "hate speech", [In:] D. Sarmento, Livres e iguais. Estudos de direito constitucional, Rio de Janeiro 2006, pp. 207-262, as well as the specialized monograph by S.M. Pflug, Liberdade de expressão e discurso do ódio. São Paulo 2009.

36 See Supremo Tribunal Federal, Habeas Corpus n. 82.424/RS, 2004, a petition filed by a defendant in criminal proceedings in which he was being accused of the crime of racism due to the fact of having published books containing provocative expressions of hatred against Jews, in addition to attempting to discredit the occurrence of the genocide committed against the Jewish people (Holocaust) during World War II. 
In a more recent decision known as the Marijuana $\mathrm{March}^{37}$, by examining the occurrence of criminal offense by virtue of the fact that freedom of speech (collectively, through assembly and manifestation) had been used to seek, through public awareness, the decriminalization of the use of soft drugs for personal consumption, the Supreme Court rejected its characterization as a condoning of crime, considering such a manifestation as covered by freedom of speech, assembly and demonstration and that public demonstrations in favor of decriminalization of a given behavior should not be confounded with incitement to commit such an act, which, in turn, would indeed involve a case of hate speech or incitement to crime not covered by freedom of speech.

However, whereas in relation to the hate speech and events of clearly anti-discriminatory nature (which, moreover, lack justification and identification) it is found - except, of course, a controversy over when in fact such manifestations do occur - that there is substantial consensus to admit stronger restrictions on freedom of speech, other cases in which freedom of speech comes into conflict with fundamental rights of third parties and other constitutional individual and collective rights present legal situations that are more complex and difficult to solve.

Among the most common situations which have already led to extensive court cases in Brazil and abroad, including recourse to the action of International Tribunals, are the prohibition of pornographic demonstrations and cultural and artistic events or expressions when considered offensive to morals (decency), good customs and even to the dignity of the human person and third party personality rights (right to privacy or publicity right). General clauses such as morals (decency) and good customs are extremely dangerous to justify restrictions on freedom of speech (except regarding age-appropriate indications, as a recommendation to parents of children and adolescents). On the other hand, usually the fact that the dignity of the human person, as a principle and fundamental right, is not questioned, and the disproportionate affection of rights of third parties, especially when it comes to personality rights (right to privacy or publicity right), must always be considered by balancing it in the light of the circumstances of each case.

37 See Supremo Tribunal Federal, Arguição de Descumprimento de Preceito Fundamental n. 187, Opinion by Justice Celso Mello, 2011. 
By evaluating the Supreme Court's case law in this context, it appears that this has generally been properly deferential to freedom of speech, allowing interventions under exceptional and usually constitutionally justified circumstances, which does not mean the impossibility of questioning the appropriateness of some court decisions or critically analyzing the reasons for such decisions, including the existence or not of a uniform, consistent and coherent position by the Supreme Court on the matter, in particular with regard to the rationality and the procedure of balancing and assessing the constitutional legitimacy of any restrictive interventions.

It seems obvious that an observation of the everyday exercise of freedom of speech and even the ensemble of Supreme Court's decisions does not to allow a superficial reading about an almost absolute preference, or even accepting only direct restraints expressly imposed by the BFC. Moreover, it is clear that the individual cases demonstrate the need for dogmatic refinement and emphasize the need to establish legal and case law criteria for the exercise of these freedoms, in harmony with other fundamental rights, without disregarding the central role that freedom of speech occupies in a democratic state.

Thus, both Claim No. 17,091, which is about the confidentiality of data belonging to financial institutions, and Claim No. 19,464, which deals with the discussion of the confidentiality of journalistic sources, which have already been presented, are representative of some dilemmas concerning freedom of speech.

In fact, the attempt to fix a limitation to freedom of speech and thought is currently on the agenda of the Supreme Court in Extraordinary Appeal No. 662,055. It should be recalled in this context that the BFSC in 08/27/2015, recognized the General Repercussion in the litigation involving an animal protection society and a legal entity of private law responsible for organizing a major rodeo in the interior of São Paulo. Taking advantage of the freedom of speech, the protection society organized campaigns on the internet, publishing messages such as "Those who sponsor and support rodeos also torture the animal”, urging citizens to send e-mails so that event sponsors could reconsider granting financial support ${ }^{38}$. In short, this association denounced

38 See Supremo Tribunal Federal, Repercussão Geral no Recurso Extraordinário n. 662.055, Opinion by Justice Roberto Barroso, 2015. 
the allegedly cruel treatment to which animals were subjected in rodeo practices and at a famous festival in the interior of São Paulo.

In turn, the event organizer asserted that false information about the treatment of animals had been presented and that no ill-treatment of animals had occurred. The plaintiff argued that instead of festivals organized by the company, e-mails with photographs of American rodeos had been sent, and it also stated that freedom of speech was used abusively with violation of the right to cultural expression, honor and image, and, additionally, that the abusive use had negative impacts on the local economy ${ }^{39}$.

The state trial court judge granted prohibitory injunction for protection of rights to honor and image, but the decision was partially overturned by the court of justice of the state of São Paulo for the purpose of a) transcribing a note on the filing of a petition on their site, b) removing the festival's name organized by the plaintiff from the list of festivals that practice mistreatment of animals, and not being allowed to c) mention the festival sponsors. Concerning the disposition of the case, it was considered partially applicable at the first level of jurisdiction, having been partially reversed by the Court of the State of São Paulo. Thus, the animal protection society was condemned to pay compensation for moral damages in the amount of $\mathrm{R} \$ 10,000.00$ (ten thousand reais) and to remove from the materials and the site information which states that the event in São Paulo inflicts cruelty on animals, not being allowed to mention the rodeo sponsors or to contact them to discourage the support. Finally, if there is non-compliance with the agreed upon obligations, the animal protection society will be sanctioned with a daily fine of $\mathrm{R}$ $\$ 5,000.00$ (five thousand reais) ${ }^{40}$.

The collated case shows the delicate balance between freedom of speech and other fundamental rights and constitutional prerogatives (environmental protection and prohibition of cruelty to animals, besides cultural rights). While it can be stated that the manifestos of the animal protection society may tarnish the honor and dignity of those affected, in addition to affecting their proprietary interest, it is also true that freedom of

39 Supremo Tribunal Federal, Repercussão Geral no Recurso Extraordinário n. 662.055, 2015, pp. 4-5.

40 Supremo Tribunal Federal, Repercussão Geral no Recurso Extraordinário n. 662.055, 2015, pp. 8-9. 
speech cannot be vacated in favor of protecting other fundamental rights. On the other hand, one must remember that what is essentially at stake concerns the discussion about the existence of unconstitutional damage to the image and property, and especially the calibration of the amount of compensation that will be able to promote an adequate recovery of the injured personality rights, but on the other hand, the fundamental right to compensation cannot be handled disproportionately, with an excessive impact on the freedom of speech.

It should be noted, moreover, that in Extraordinary Appeal No. 662,055 a prohibitory injunction was attributed to protect the event organizer and its sponsors. In this context, it can be said that while emergency injunctions are a necessary and natural consequence of the right to a due process involving a rapid proceeding in order to achieve its goal, the granting of an emergency injunction for the protection of personality or publicity rights with a restraint on freedom of speech must be an action taken with extreme caution and only in exceptional cases, when the prohibitive injunction is shown to be indispensable to prevent a serious violation of conflicting fundamental rights, particularly when it results in clear violation of human dignity.

It should be recalled, still on this issue, that, in that judgment, the Supreme Court, by unanimous vote in the virtual plenary, showed that it will set the restraints for the exercise of freedoms of speech and thought, which is evident in the passage transcribed here: The constitutional issue in question consists of defining the restraints of freedom of speech, even if exercising it may result in relevant commercial damage as well as of setting parameters to identify cases in which the publication should be prohibited and/or the declarant sentenced to pay compensation for moral damages or other legal consequences that may be legitimately imposed ${ }^{41}$.

With this decision we can see that the Supreme Court has mitigated the guidance given by the author of the opinion on ADPF No. 130 (Supreme Court Justice Carlos Britto), accepting, at least in principle, other restrictive interventions in the freedom of speech apart from those expressly established by the BFC.

${ }^{41}$ Supremo Tribunal Federal, Repercussão Geral no Recurso Extraordinário nº. 662.055, 2015, p. 14. 
However, even though freedom of speech (including the free expression of thought) has not been subject to an explicit legal reservation, any imposition of restrictions should be, first and foremost and as a rule, disseminated by democratically legitimized legislators and always in compliance with the criteria of proportionality and protection of the essential core of communicative fundamental rights.

Along these lines, it is important - as part of an appropriate construction and understanding of the weighting criteria in cases of conflicts between freedom of speech and other crucial constitutional rights - that an interpretive vector lies in understanding the need for an equilibrium in the interpretation of freedom of speech on the basis of liberal (freedom of speech as a right of a person regardless of its consequences and the role played by this freedom in the community), democratic (freedom of speech as a condition for democracy and pluralism) and Republican values (use of freedom of speech in order to obtain and disseminate information and manifestations on the public sphere and people who work in public service). Such political and legal traditions cannot be separated and occupy a prominent place in the relational assessment of freedom of speech in the constitutional architecture of a democratic state.

Despite the significance of these vectors, it must be agreed that they are open and make it difficult to concretely control the boundaries between freedom of speech and conflicting rights and principles. Thus, there is no way to dispense with a judgment of proportionality and/or reasonableness when strictly necessary, but especially it is necessary to take into account relevant criteria which are already widely recognized and, even not dismissing a legal rationality in particular, have served as a relatively safe and substantial consensual guide, such as the prohibition of the so-called "hate speech" and discrimination, as well as the prohibition of obvious and serious offenses to human dignity and personality rights which are related to them. Moreover, any prohibitory injunction is to maintain an exceptional character and be managed only when actually necessary to protect fundamental rights or other constitutional rights from offense that is so serious that the absence of an emergency injunction could lead to irreparable damage.

As a possible example of the misuse of freedom of speech, subject to the use of the exceptional prohibitory injunction, one can mention the brutal viola- 
tion of intimacy, privacy, image and honor for the dissemination of false information in the famous case of Escola Base in São Paulo. In March 1994, the school's owners and a couple of parents were accused of systematically promoting sexual violence on the children at that private school). There were said to be orgies with children in sex rituals with drugs use. Nothing was proved, but the moral and material damages to the defendants were so intense that they resulted in serious threats to their personal and even to their families' integrity ${ }^{42}$. Nevertheless it must be emphasized that the example now collated reveals how exceptional are situations in which, in principle, emergency injunction is properly applicable.

Added (and even as a supplement) to the criteria mentioned above, it can be mentioned that other guidelines may be added to the existing ones. One of them concerns the dissemination of untrue information intentionally or with gross negligence, a situation in which the theory of actual malice would be applied, which would be necessary to consider such a situation a misuse of freedom of speech. If such a theory, which was highlighted in the case of New York Times vs. Sullivan ${ }^{43}$, is open to criticism as to what may be conceived as an exaggerated position with regards to freedom of speech, it is also true that building a robust civil, critical, and democratic society presupposes access to information and the dissemination of information, which would be significantly impaired if small mistakes about factual content would justify the award of compensations or even other consequences.

Moreover, one must keep in mind that the use of freedom of speech for fictional and artistic situations, even if acidic and with potential damage to the image and honor of individuals, should be in principle accepted ${ }^{44}$. In this sense, as Jónatas Machado correctly points out, "satirical speech and carica-

42 Supremo Tribunal Federal, Arguição de Descumprimento de Preceito Fundamental n. 130, Opinion by Justice Carlos Ayres Britto, 2009, pp. 256-258.

43 See U.S. Supreme Court, New York Times Co. vs. Sullivan, 376, 1964, pp. 254-305.

44 About the relationship between artistic freedom and freedom of speech, presenting and reflecting on artistic movements and controversial situations of collision with other values and constitutional prerogatives, see A.S. Kurzweg, Live art and the audience: toward the speaker-focused freedom of speech, "Harvard Civil Rights - Civil Liberties Law Review" 1999, Vol. 32, pp. 438-485. 
ture have been used since ancient times as instruments of social criticism, thus having a solid pedigree." ${ }^{5}$

It is noteworthy to recall the decision of the U.S. Supreme Court in the case Hustler Magazine Inc. vs. Falwell, and the - in our opinion erroneous decision by the German Bundesverfassungsgericht regarding the caricature in Konkret magazine, both of which cases have already been briefly described. The formulation of criticism against a Christian authority, albeit in bad taste and based on acknowledged fictions in Hustler magazine, does not hinder the protection of freedom of speech, as well as the formulation of cartoons denouncing spurious relations between the Executive and the Judicial Power in a German member-state are - in contrast with the decision of the German Supreme Court included within the sphere of protection of freedom of speech (in this case, also artistic freedom) especially as they refer to public personalities and the subjects dealt with are issues of public interest and essential to a democratic state. Regarding the case of Hustler magazine, the express recognition that this is fiction clearly built as criticism of hegemonic social and religious views clearly shows the use of freedom of speech in a relevant subject.

Moreover, it should be noted that when the information is obtained by unlawful means its disclosure is usually also considered inadmissible ${ }^{46}$. It is important to keep in mind that according to the Brazilian positive constitutional law, the inviolability of the home is a fundamental right and only in the event of disaster, flagrante delicto, giving help or, during the day, by court order may one enter therein without the consent of the owner or resident (art. 5, XI, $\mathrm{BFC}$ ). The same occurs in cases of inviolability of correspondence, telegraphic communications, data and telephone confidentiality. The latter can be broken only by court order, in the cases and in the manner prescribed by the law for the purposes of criminal investigation or criminal procedural fact-finding (art. 5, XII, BFC), and it also expressly provided that evidence obtained through illicit means is unacceptable in the proceedings (art. 5, LVI, BFC) ${ }^{47}$.

\footnotetext{
45 J.E.M. Machado, op.cit., p. 824.

46 L.R. Barroso, op.cit., p. 327.

47 About fundamental and human rights that protect intimacy, privacy, home, and the impossibility of obtaining and using illegal evidence, see N.J. Giacomolli, O devido processo penal: abordagem conforme a Constituição Federal e o Pacto de São José da Costa Rica, 2 ed. São Paulo 2015.
} 
One must not forget also art. 17 of the Covenant on Civil and Political Rights and art. 11, 2, of the American Convention on Human Rights (ratified by Brazil in 1992), which forbid arbitrary, abusive and illegal interference in private life, home, family life and correspondence.

An especially complex topic is safeguarding the confidentiality of the source of information in accordance with the provisions of art. 5, XIV, BFC, an innovative constitutional provision, but which may, depending on the case, be in conflict with the impossibility of using evidence and information obtained illegally. This situation is even more dramatic when the manner in which the information was obtained is a criminal offense. First, the right to safeguard the confidentiality of the source is an essential guarantee for the proper exercise of the freedoms of speech and of the press, ensuring the necessary journalists independence in relation to state authorities and in face of the newspaper publishing company itself, besides establishing a structure of trust by citizens in presenting important information to the community through the press ${ }^{48}$.

Thus, as long as the journalist and the communication mechanism do not operate jointly with the source to obtain illicit information, it is not possible consider them criminally or civilly liable for using information obtained illicitly by the source, especially if it deals with a public issue of relevant social interest. In this situation, the criteria of the nature of the fact and the existence of public interest prevail over the protection against information obtained illicitly. On the other hand, the constitutionally established autonomy for the benefit of journalists and society on the confidentiality of the source does not hinder the attempt to obtain compensation for presenting false facts disseminated by the journalistic source ${ }^{49}$. Precisely in this context, particularly in the field of freedom of speech in its aspects of social communication (journalism), the figure of pursuance of legitimate interests becomes important, excluding the criminal liability of the journalist, a topic that, despite its relevance, cannot be addressed here, although it is closely connected to the problems that we have discussed in this article ${ }^{50}$.

48 H. Masnatta, Hábeas data y secreto de las fuentes de información periodística, [In:] Nuevos derechos a la informacion, ed. H. Chumbita, Buenos Aires 1999, pp. 24-25.

49 See W. Steinmetz, Comentários ao artigo 5o, XIV, CF, [In:] J.J. G. Canotilho, G.F. Mendes, I.W. Sarlet, L.L. Streck, Comentários à Constituição Federal de 1988, São Paulo 2013, p. 300.

so See J.H. Weingartner Neto, op.cit. 
Even the publication or dissemination of public facts obtained lawfully by the press can very seriously damage the honor, image and dignity of people, but as a rule freedom of speech should prevail in such a way that only in exceptional cases restrictions are legally legitimate. It is a presumption in favor of freedom of speech, which may be removed if it is demonstrated that the disclosure of such information intensively affronts other fundamental rights.

Based on what was mentioned above, we cannot agree, for example, with the decision of the U.S. Supreme Court (1975) in Cox Broadcasting vs. Cohn, which considered: i) lawful the publication of news stories with the identity of rape victims and ii) unconstitutional the state law that prohibited the disclosure of names of rape victims ${ }^{51}$. The situation of rape, besides the physical damage, has profound moral and psychic consequences on the victims. Therefore, the publication of rape victims' names, although available in public archives, only increases the non-material damage. On the basis of the analysis of this particular situation, it should be considered that the right to privacy and the protection of dignity may prevail and rebut the protection of the publication of public information by the press, when i) the conflict with those personal rights is intense and ii) if the information presented is not of public interest, because, if no other reason pertains, there is no legitimate public interest in knowing the names of people raped in a certain place, and, on the other hand, it is of public interest to be aware of the occurrence of rapes (their investigation), the most frequent places where they occur, the conviction rate of the accused, the measures of prevention, among other information. In addition, the non-disclosure of the victims' names and other personal identification data do not inhibit the access to information that can actually be of public interest.

51 "The State may not, consistently with the First and Fourteenth Amendments, impose sanctions on the accurate publication of a rape victim's name obtained from judicial records that are maintained in connection with a public prosecution and that themselves are open to public inspection. Here, under circumstances where appellant reporter based his televised report upon notes taken during court proceedings and obtained the rape victim's name from official court documents open to public inspection, the protection of freedom of the press provided by the First and Fourteenth Amendments bars Georgia from making appellants' broadcast the basis of civil liability in a cause of action for invasion of privacy that penalizes pure expression -- the content of a publication" (U.S. Supreme Court, Cox Broadcasting vs. Cohn, 420, 1975, p. 470). 
On the other hand, regarding discourses which deny notorious facts and in their utterance exercise so-called hate speech against a social, ethnic, religious or racial group, it is known that there are different legal traditions and different views on these phenomena. In this context, the difficulty in understanding the historical events, which not infrequently allow multiple interpretations, is not disregarded. On the other hand, it is undeniable that in the case of the Holocaust, which caused the death of millions of Jews during World War $\mathrm{II}^{52}$, as well as other widely documented situations (for example, victims of Stalinist and Maoist totalitarianism), it is correct - in our opinion - to assert that theses that deny such facts, especially if accompanied by value judgments in favor of historical events that have occurred, cannot deserve protection based on freedom of speech, so that the Brazilian Supreme Court's decision in the famous case of Ellwanger presented above was correct.

Apropos of this issue, here we mention the existence of another legal tradition, according to which it is not possible to civilly and criminally punish people who disseminate rejection speech or who affirm the existence of highly derogatory characteristics of another social group ${ }^{53}$. In Brandenburg vs. Ohio the American Supreme Court declared that hate speech and racist speeches are covered by freedom of speech and freedom of the press. In this case, it was stated that a leader of the Ku Klux Klan, by presenting racist speeches against blacks and Jews during television stories, did not commit any unlawful act, as his act would be sustained by the principle of freedom of speech $^{54}$. Just as the economic market has flaws that prevent

52 Ti should be noted that tehere are intense academic discussions in the historical context of the Holocaust; see L. Bilsky, The judge and the historian: holocaust transnational litigation as a new model, "History and Memory" 2012, Vol. 24, No. 2, pp. 117-156. On the other hand, it is not possible to deny the systematic racial and cultural Nazi persecution of the Jews, and especially the death of millions of people.

53 On the other hand, for a position saying that hate speech is not covered by freedom of speech, see J. Waldron, The harm in hate speech, Cambridge 2012.

54 This was the U.S. Supreme Cout's decision: “Appellant, a Ku Klux Klan leader, was convicted under the Ohio Criminal Syndicalism statute for 'advocat[ing] the duty, necessity, or propriety of crime, sabotage, violence, or unlawful methods of terrorism as a means of accomplishing industrial or political reform' and for 'voluntarily assembl[ing] with any society, group or assemblage of persons formed to teach or advocate the doctrines 
its proper performance and impose interventions and restraints on economic agents, the so-called free market of ideas, despite being a relevant regulative ideal which advocates public and social criticism through public debate as an antidote to the oppressive and hateful speeches, it should be restricted in exceptional situations, such as hate speech. This does not mean to defend the ideology of political correctness and public execration of social debates which are not under its umbrella, but it means repudiating discriminatory speeches or those which are motivated by hatred and sectarianism ${ }^{55}$.

Another usual parameter for measuring the restraints on freedom of speech in cases of conflict with personal rights is the social position occupied by a particular person. As regards the rights to honor and image, one has to immediately distinguish cases involving public personalities, as in the case of famous artists, politicians and other people whose activity and behavior in the public sphere make them different from other persons, also ensuring different levels of personality protection depending on the particular case of who is affected by the exercise of freedom of speech and how they are affected. For this reason, in situations of (legitimate) public interest in information about someone's actions and private life, and especially, when the holder of personality rights, right to privacy or publicity rights themselves have already voluntarily exposed their private life, a lower level of protection - but not suppression! - of honor, image, private and intimate life and a larger space for freedom of information and speech are justified.

of criminal syndicalism.' Neither the indictment nor the trial judge's instructions refined the statute's definition of the crime in terms of mere advocacy not distinguished from incitement to imminent lawless action. Held: Since the statute, by its words and as applied, purports to punish mere advocacy and to forbid, on pain of criminal punishment, assembly with others merely to advocate the described type of action, it falls within the condemnation of the First and Fourteenth Amendments. Freedoms of speech and press do not permit a State to forbid advocacy of the use of force or of law violation except where such advocacy is directed to inciting or producing imminent lawless action and is likely to incite or produce such action. Whitney v. California, 274 U.S. 357, overruled” (U.S. Supreme Court, Brandenburg vs. Ohio, 395, 1969, p. 444).

55 About political correctness and freedom of expression, see J.E.M. Machado, op.cit., pp. $845-846$. 
V.

State restrictions on freedom of speech in its diverse dimensions represent a strong restraint to the enjoyment of those rights and the structure of the democratic state itself.

In the event of a conflict between freedom of speech (always taken here in its broadest sense) and personality rights (intimacy, privacy, honor and image) and even the dignity of the human person itself, the above suggested guidelines establish relevant criteria for the appropriate judicial balancing in each case. Thus, the truth of the fact is a matter that needs to be taken into account in a democratic society, but this criterion must be reconciled with the doctrine of actual malice and the established protection of fictional and artistic discourses even if these conflict with the personality, right to privacy and publicity rights. Still, discourses aiming at violating the factual truth with the purpose of at attacking social, ethnic, religious and political groups as a rule are not protected by freedom of speech when they involve hate speech or imply obvious discrimination and, additionally, violate the dignity of the human person. In turn, the lawfulness of the means used in obtaining information is central, but the confidentiality of journalistic sources allows the publication of illegal information provided that this contributes to the democratic discussion and that there is no involvement of the press and journalists in obtaining illegal information.

On the other hand, the protection of the rights to honor, image and privacy of public or "famous" figures is generally guaranteed in a less intense way; the more prominent the public figure, the less intense are their rights to protection. Furthermore the location and nature of the fact, as well as the existence of public interest, are important elements and require ensuring freedom of speech more effectively. Finally, the prohibitive injunction, in exceptional cases of prevalence of personality rights, right to privacy and publicity rights, might be considered, but requires higher argumentative skills of judges, as repressive protection remains the guarantee of freedom of speech. 


\section{Literature}

Barroso L.R., Colisão entre liberdade de expressão e direitos da personalidade. Critérios de ponderação. Interpretação constitucionalmente adequada do Código Civil e da Lei de Imprensa, "Revista latino americana de estudos constitucionais" 2005, No. 5.

Bilsky L., The judge and the historian: holocaust transnational litigation as a new model, "History and Memory" 2012, Vol. 24, No. 2.

Branco P.G.G., Liberdades, [In:] G.F. Mendes, P.G.G. Branco, Curso de direito constitucion$a l, 6^{\text {th }}$ ed., São Paulo 2011.

Canotilho J.J.G., Moreira, V., Constituição da República portuguesa anotada, $4^{\text {th }}$ ed., Coimbra 2007.

Epping V., Grundrechte, $3^{\text {rd }}$ ed., Berlin-Heidelberg-New York 2007.

Farias E., Liberdade de expressão e comunicação: teoria e proteção constitucional, São Paulo 2004.

Fechner F., Art. 5, Meinungsfreiheit, Pressefreiheit u.a. [In:] Stern-Becker, Grundrechte-Kommentar, Köln 2010.

Giacomolli N.J., O devido processo penal: abordagem conforme a Constituição Federal e o Pacto de São José da Costa Rica, 2 ed. São Paulo 2015.

Koatz R.L.-F., As liberdades de expressão e de imprensa na jurisprudência do STF, [In:] Direitos fundamentais no Supremo Tribunal Federal: balanço e crítica, eds. D. Sarmento, I.W. Sarlet, Rio de Janeiro 2011.

Kurzweg A.S., Live art and the audience: toward the speaker-focused freedom of speech, "Harvard Civil Rights - Civil Liberties Law Review" 1999, Vol. 32.

Machado J.E.M., Liberdade de expressão: dimensões constitucionais da esfera pública no sistema social, Coimbra 2002.

Masnatta H., Hábeas data y secreto de las fuentes de información periodística, [In:] Nuevos derechos a la informacion, ed. H. Chumbita, Buenos Aires 1999.

Michael L., Morlok M., Grundrechte, Baden-Baden 2008.

Michelman, F., Relações entre democracia e liberdade de expressão: discussão de alguns argumentos, [In:] Direitos fundamentais, informática e comunicação, eds. I.W. Sarlet, Porto Alegre 2007.

Pflug, S.M. Liberdade de expressão e discurso do ódio, São Paulo 2009.

Sarmento D., A liberdade de expressão e o problema do "hate speech", [In:] D. Sarmento, Livres e iguais. Estudos de direito constitucional, Rio de Janeiro 2006.

Sarmento D., Comentários ao artigo 5, IV, CF, [In:] J.J. G. Canotilho, G.F. Mendes, I.W. Sarlet, L.L. Streck, Comentários à Constituição Federal de 1988, São Paulo 2013 Silva, J.A. da., Curso de direito constitucional positive, $28^{\text {th }}$ ed. rev. and updated. São Paulo 2007 . 
Steinmetz W., Comentários ao artigo 50, XIV, CF, [In:] J.J. G. Canotilho, G.F. Mendes, I.W. Sarlet, L.L. Streck, Comentários à Constituição Federal de 1988, São Paulo 2013. Sunstein C.R., Democracy and the problem of free speech, New York 1995.

Waldron J., The harm in hate speech, Cambridge 2012.

Weingartner Neto J.H., Privacidade e liberdade de imprensa. Uma pauta de justificação penal, Porto Alegre 2002. 